\title{
Motor neurone disease with elevated cerebrospinal fluid protein
}

\author{
R J GUILOFF, B McGREgOR, E THOMPSON, W BLACKWOOD, AND E PAUL \\ From the National Hospitals for Nervous Diseases, Queen Square, London
}

SUMMARY The correlation between age and CSF protein in 38 patients with pathologically proven motor neurone disease was the reverse of that described for normal subjects by Tibbling et al in 1977. Eight had CSF protein ranging from $0.75 \mathrm{~g} / 1$ to $1.52 \mathrm{~g} / \mathrm{L}$. These patients were younger, but other clinical and gross and light microscopy pathological features were not significantly different from those with lower CSF protein. Transudation from serum may be only one of the mechanisms underlying this elevation in CSF protein.

It has been known for a long time that patients with motor neurone disease (MND) may have elevated total protein in the cerebrospinal fluid (CSF) ${ }^{12}$; but its clinical significance, if any, has not been studied and its precise mechanism remains obscure. Some recent reports still include a normal CSF as one of the criteria used for a clinical diagnosis of MND..$^{3-5}$

These considerations prompted us to investigate the natural history, CSF findings and pathology in a group of 38 patients with MND, particularly in eight of them whose total CSF protein ranged from $0.75 \mathrm{~g} / 1$ to $1.52 \mathrm{~g} / 1$.

\section{Material and methods}

Thirty-eight cases of MND with pathological confirmation of the diagnosis were studied. Thirty-seven of the cases were obtained from the records of the Pathology Department of the National Hospital, Queen Square, between 1952 and 1975 inclusive. The clinical records and CSF examination were available in all, and the histological findings were diagnostic of MND on review. The other case had postmortem examination elsewhere.

The clinical picture obtained at the first full neurological assessment was classified as follows:

(1) Amyotrophic lateral sclerosis (ALS), 23 patients; simultaneous occurrence of lower and upper motor neurone signs in one or more limbs.

(2) Progressive muscular atrophy (PMA), 4

Address for reprints: Dr RJ Guiloff, National Hospitals for Nervous Diseases, Queen Square, London WC1N 3BG.

Accepted 7 February 1980 patients; lower motor neurone signs only in one or more limbs.

(3) Progressive bulbar palsy (PBP), 3 patients; flacoid or spastic paralysis of bulbar muscles with or without pyramidal signs in the limbs.

(4) Mixed (M), 8 patients; any combination of the first three.

Other variables obtained were: (table 2)

a: Age at onset of the first symptom attributable to MND

b: Age at time of lumbar puncture

c: Age at death

$\mathrm{d}$ : Time to severe incapacity: from onset of first symptoms to date when it was stated that the patient had become bed or chairridden or unable to work, or had disabling bulbar symptoms

e: Duration of illness: from onset of first symptom to death

f: Time from onset to lumbar puncture

g: Time from lumbar puncture to death

$\mathrm{h}$ : Time from severe incapacity to death

i: $\mathrm{CSF}$ protein in $\mathrm{g} / \mathrm{l}$

j: Sex: there were 24 males and 14 females.

The CSF protein was estimated by the trichloroacetic acid method ${ }^{6}$ in 31 patients and by the sulphosalicylic acid $\operatorname{method}^{7}$ in five patients. The method was not known in two. In two other patients the numerical value of the CSF protein was not stated although it was noted that it was normal. These cases were not used in correlations requiring a numerical value for the CSF protein but were included in the clinical analysis as cases with normal CSF protein.

The pathological reports and histological sections were reviewed in 37 cases. Particular 
attention was paid to the eight cases with CSF protein $\geqslant 0.75 \mathrm{~g} / 1$, in seven of whom the pathological material was available for review. In these seven, sections had been taken from one or more levels of the spinal cord and in most of them, from the medulla and from the region of the motor cortex. Other sites had been sampled in some cases. Material had been embedded in both paraffin wax and celloidin, and when sectioned had been stained by a variety of methods to demonstrate myelin (Luxol Fast Blue, Loyez, Weigert Pal), glial fibres (phosphotungstic acid haemotoxylin), fat (Sudan IV on frozen sections), axons (Holmes), collagen (haematoxylin van Gieson), and general structures (haematoxylin and eosin). Three had skeletal muscle sections and one a section of the anterior tibial nerve.

\section{Results}

\section{A Statistical analysis}

In our series there was a negative correlation botween CSF protein and the age at which the CSF was obtained. A positive correlation between CSF protein and age, in normals, has been found by others. ${ }^{8}$ The difference between the correlation coefficient in our MND patients and that found by Tibbling et al in normals is highly significant (table 1). The proportion of males to females in our data was the reverse of the proportion in Tibbling et al's series. These authors had 59 females and 34 males. The difference between our mean CSF protein levels in men $(0.59 \mathrm{~g} / 1)$ and women $(0.45 \mathrm{~g} / 1)$ was not significant. Mean protein levels for men and women separately were not available for the Tibbling et al series. To check that the finding of a negative correlation between CSF protein and age in MND patients was not an artefact of the sex ratio, we calculated the correlation coefficient separately for men and women. Both were negative (males $\mathrm{r}=-0 \cdot 22, \mathrm{n}=-22$; females $\mathrm{r}=-0.62, \mathrm{n}=14)$.

Patients with ALS had a higher mean CSF protein than all patients with other forms of the disease but the difference was not significant.

None of the time variables (time to severe incapacity, duration of illness, time from onset to lumbar puncture and time from lumbar punoture to death) were normally distributed, so $\log$ transformations were taken to normalise the data.

Log time to severe incapacity and log duration of illness were highly correlated (fig). In 11 patients time to severe incapacity could not be determined from the clinical notes. We found no difference in duration of illness between these 11 patients and the rest of the series.

There was no significant relationship between CSF protein level and both log duration of illness and log time to severe incapacity.

\section{$B$ Clinical features}

Table 2 shows a comparison between the 30 patients with CSF protein below $0.75 \mathrm{~g} / 1$ and the eight with CSF protein $\geqslant 0.75 \mathrm{~g} / 1$. Patients with CSF protein $\geqslant 0.75 \mathrm{~g} / 1$ were younger at age of onset, age at lumbar puncture and age at death than patients with lower CSF protein levels but they did not differ significantly from them in the

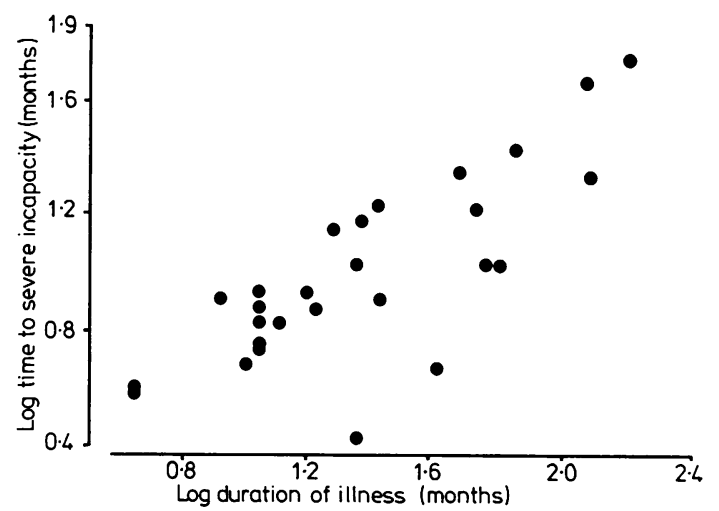

Figure Correlation coefficient $r=0 \cdot 80, n=27$, $p=0.00001$. See results.

Table 1 CSF protein and age in Normals and MND patients

\begin{tabular}{|c|c|c|c|c|c|c|c|}
\hline \multirow{3}{*}{$\begin{array}{l}\text { Age } \\
\text { range }\end{array}$} & \multicolumn{3}{|c|}{ Normals* } & \multicolumn{4}{|c|}{ MND† } \\
\hline & \multicolumn{2}{|c|}{$\overline{C S F \text { Protein } \mathrm{g} / 1}$} & \multirow{2}{*}{$\begin{array}{l}\text { No of } \\
\text { cases }\end{array}$} & \multicolumn{2}{|c|}{ CSF Protein $\mathrm{g} / 1$} & \multirow[t]{2}{*}{ Range } & \multirow{2}{*}{$\begin{array}{l}\text { No of } \\
\text { cases }\end{array}$} \\
\hline & Mean & $S D$ & & Mean & $S D$ & & \\
\hline $17-30$ & $0 \cdot 367$ & 0.063 & 21 & & & & $\{1$ \\
\hline $31-34$ & $0 \cdot 363$ & 0.061 & 18 & 0.638 & $0 \cdot 180$ & $0.40-0.80$ & $\{3$ \\
\hline $41-50$ & 0.433 & 0.079 & 22 & 0.776 & 0.379 & $0.40-1.52$ & 9 \\
\hline $51-60$ & 0.479 & 0.094 & 21 & 0.469 & $0 \cdot 207$ & $0 \cdot 20-1 \cdot 00$ & 13 \\
\hline$<60$ & 0.526 & 0.013 & 11 & 0.378 & 0.129 & $0.20-0.55$ & 10 \\
\hline Totals & 0.426 & 0.040 & 93 & 0.539 & $0 \cdot 281$ & $0 \cdot 20-1 \cdot 52$ & 36 \\
\hline
\end{tabular}


Table 2 Clinical features of MND patients with CSF protein $\geqslant 0.75 \mathrm{~g} / \mathrm{l}$ and with CSF protein $<0.75 \mathrm{~g} / \mathrm{l}$

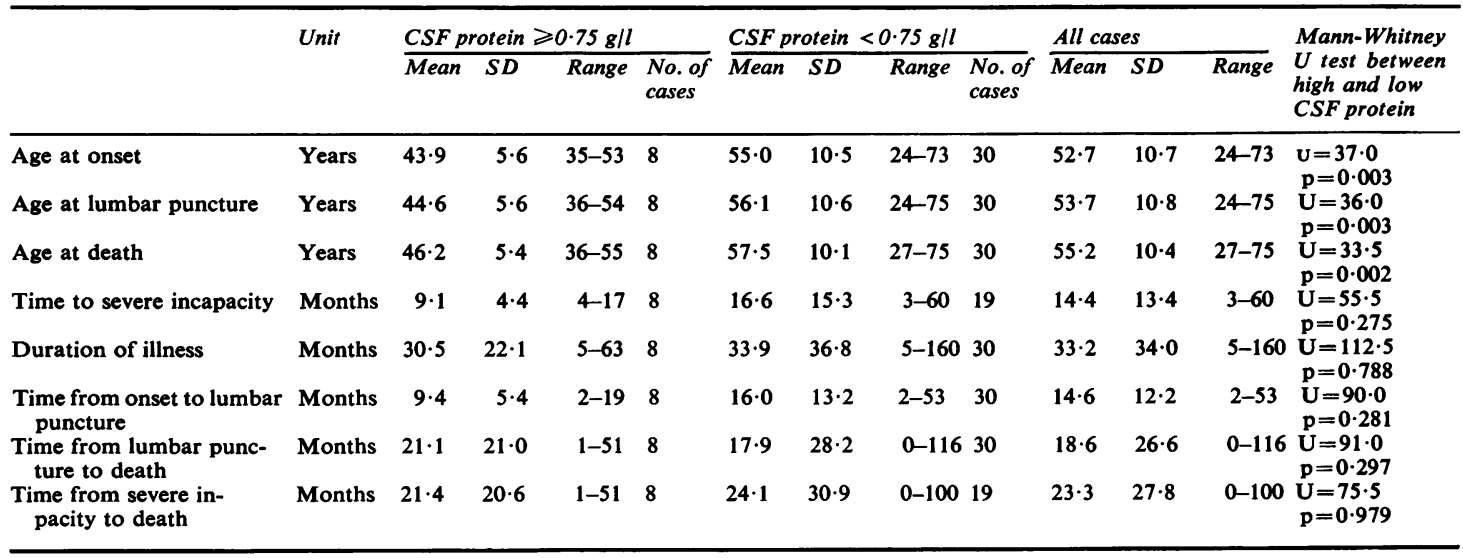

total duration of their illness. Their mean time to severe incapacity was shorter but the difference was not significant. Other clinical features of the eight patients were comparable to those of patients with CSF protein $<0.75 \mathrm{~g} / 1$. Two familial cases were seen in the first group (cases 1 and 8) and one in the second. A variety of illnesses was ncted in the past history of both groups, but in neither was polymyelitis mentioned. Trauma was considered an apparently precipitating factor in six patients with low CSF protein and in one with increased CSF protein. A flu-like illness preceding the onset was mentioned in two patients with low CSF protein and a skin rash in one patient in each group. Inspection of the data on first symptoms and patterns of wasting and weakness, fasciculations, tendon reflex abnormalities and plantar responses showed no major differences between the two groups. Table 3 summarises the clinical data on the patients with raised protein.

\section{CSF findings}

Full CSF analysis was known in all but two cases (see Methods). Table 4 shows the results in those with CSF protein $\geqslant 0.75 \mathrm{~g} / 1$.

In six of the 38 cases serum protein levels and electrophoresis, or CSF protein electrophoresis or both, were available (table 5). Of the two cases with CSF protein $\geqslant 0.75 \mathrm{~g} / 1$, one (case 7) had both normal serum protein electrophoresis and CSF protein electrophoresis. The other (case 5) had a CSF IgG of $12.1 \%$ but no serum protein studies. Of the four patients with CSF protein $<0.75 \mathrm{~g} / 1$ three had normal serum protein levels and electrophoresis. The fourth had a raised IgG in the CSF (16.3\%) (normal up to $12 \%$ of total protein) but had no serum protein studies.

\section{Pathological findings}

The cord was described as small, thin or atrophic in many patients. Atrophy or abnormality of the anterior spinal roots was reported in most. Table 6 summarises the histological changes in the seven cases with CSF protein $\geqslant 0.75 \mathrm{~g} / 1$ available for review.

Motor neurone loss, with degenerative changes in some or many residual neurones was seen in

Table 3 Main clinical features in 8 patients with MND and CSF protein $\geqslant 0.75 \mathrm{~g} / \mathrm{l}$

\begin{tabular}{|c|c|c|c|c|c|c|c|}
\hline Patient & Sex & Clinical form & $\begin{array}{l}\text { Duration of } \\
\text { illness } \\
\text { (months) }\end{array}$ & $\begin{array}{l}\text { Time to severe } \\
\text { incapacity } \\
\text { (months) }\end{array}$ & $\begin{array}{l}\text { Age at onset } \\
\text { (years) }\end{array}$ & $\begin{array}{l}\text { Age at LP } \\
\text { (years) }\end{array}$ & $\begin{array}{l}\text { Age at death } \\
\text { (years) }\end{array}$ \\
\hline $\begin{array}{l}1 \\
2 \\
3 \\
4 \\
5 \\
6 \\
7 \\
8\end{array}$ & $\begin{array}{l}\mathbf{F} \\
\mathbf{M} \\
\mathbf{M} \\
\mathbf{M} \\
\mathbf{M} \\
\mathbf{F} \\
\mathbf{M} \\
\mathbf{F}\end{array}$ & $\begin{array}{l}\text { PMA } \\
\text { ALS } \\
\text { ALS } \\
\text { ALS } \\
\text { ALS } \\
\text { ALS } \\
\text { ALS } \\
\text { M }\end{array}$ & $\begin{array}{r}5 \\
24 \\
41 \\
12 \\
63 \\
60 \\
12 \\
27\end{array}$ & $\begin{array}{r}4 \\
17 \\
5 \\
6 \\
12 \\
12 \\
8 \\
9\end{array}$ & $\begin{array}{l}47 \\
46 \\
42 \\
35 \\
44 \\
38 \\
46 \\
53\end{array}$ & $\begin{array}{l}47 \\
47 \\
42 \\
36 \\
45 \\
39 \\
47 \\
54\end{array}$ & $\begin{array}{l}47 \\
48 \\
42 \\
36 \\
49 \\
43 \\
47 \\
55\end{array}$ \\
\hline
\end{tabular}

PMA = Progressive muscular atrophy; $A L S=$ Amyotrophic lateral sclerosis; $M=$ Mixed form; $\mathbf{L P}=\mathbf{L u m b a r}$ puncture. 
Table 4 Full CSF findings in 8 cases of MND with total CSF protein $\geqslant 0.75 \mathrm{~g} / \mathrm{l}$

\begin{tabular}{|c|c|c|c|c|c|c|c|c|c|c|}
\hline Case & $\begin{array}{l}\text { Pressure } \\
\mathrm{mm} \mathrm{H}_{2} \mathrm{O}\end{array}$ & Appearance & $\begin{array}{l}\text { Protein } \\
\mathrm{g} / 1\end{array}$ & Pandy & Lange & $\begin{array}{l}\text { WBC } \\
\text { per } \mathrm{mm}^{3}\end{array}$ & $\begin{array}{l}R B C \\
\text { per } \mathrm{mim}^{3}\end{array}$ & $\begin{array}{l}\text { Sugar } \\
m m / 1\end{array}$ & Wasserman & Others \\
\hline $\begin{array}{l}1 \\
2 \\
3 \\
4 \\
5\end{array}$ & $\begin{array}{l}85 \\
\text { NK } \\
180 \\
\text { NK } \\
160\end{array}$ & $\begin{array}{l}\text { Clear colourless } \\
\text { NK } \\
\text { Clear colourless } \\
\text { Turbid colourless } \\
\text { Clear colourless }\end{array}$ & $\begin{array}{l}0 \cdot 84 \\
1 \cdot 20 \\
0 \cdot 80 \\
0 \cdot 75 \\
0 \cdot 75\end{array}$ & $\begin{array}{l}\text { NK } \\
\text { NK } \\
\text { Positive } \\
\text { Positive } \\
\text { Weakly } \\
\text { positive }\end{array}$ & $\begin{array}{l}1112210000 \\
\text { No change } \\
0011100000 \\
\text { No change } \\
\text { No change }\end{array}$ & $\begin{array}{l}0 \\
0 \\
2 \text { lymph } \\
2 \text { lymph } \\
2 \text { lymph }\end{array}$ & $\begin{array}{l}128 \\
248 \\
0 \\
2300 \\
160\end{array}$ & $\begin{array}{l}\text { NK } \\
\text { NK } \\
\text { NK } \\
\text { "normal" } \\
\text { NK }\end{array}$ & $\begin{array}{l}\text { NK } \\
\text { Negative } \\
\text { Negative } \\
\text { Negative } \\
\text { Negative }\end{array}$ & $\begin{array}{l}\text { Prealbumin } 4 \cdot 1 \% \\
\text { Albumin } 48 \cdot 1 \% \\
\text { B globulin } 9 \cdot 8 \% \\
\text { IgA } 1 \% \\
\text { IgG } 12 \cdot 1 \% \text { (PAGE) }\end{array}$ \\
\hline $\begin{array}{l}6 \\
7 \\
8\end{array}$ & $\begin{array}{l}\text { NK } \\
95 \\
130\end{array}$ & $\begin{array}{l}\text { Clear colourless } \\
\text { Clear colourless } \\
\text { Clear colourless }\end{array}$ & $\begin{array}{l}0 \cdot 80 \\
1 \cdot 52 \\
1 \cdot 00\end{array}$ & $\begin{array}{l}\text { Positive } \\
\text { Positive } \\
\text { Weakly } \\
\text { positive }\end{array}$ & $\begin{array}{l}\text { No change } \\
\text { No change } \\
\text { No change }\end{array}$ & $\begin{array}{l}1 \text { lymph } \\
0 \\
0\end{array}$ & $\begin{array}{l}\mathbf{0} \\
\mathbf{0} \\
\mathbf{0}\end{array}$ & $\begin{array}{l}\text { NK } \\
0 \cdot 47 \\
\text { NK }\end{array}$ & $\begin{array}{l}\text { Negative } \\
\text { Negative } \\
\text { Negative }\end{array}$ & IgG $4.6 \%$ \\
\hline
\end{tabular}

NK $=$ not known $\quad$ PAGE $=$ Polyacrylamide gelelectrophoresis

Table 5 CSF and serum protein findings in 6 patients with MND

\begin{tabular}{|c|c|c|c|c|c|c|c|}
\hline \multirow[t]{2}{*}{ Case } & \multirow{2}{*}{$\begin{array}{l}C S F \\
\text { protein } g / 1 \\
\text { method }\end{array}$} & \multicolumn{2}{|c|}{ Serum protein $\mathrm{g} / 1$} & \multirow{2}{*}{$\begin{array}{l}\text { CSF protein } \\
\text { electrophoresis } \\
\text { method }\end{array}$} & \multirow{2}{*}{$\begin{array}{l}\text { Serum protein } \\
\text { electrophoresis } \\
\text { method }\end{array}$} & \multirow{2}{*}{$\begin{array}{l}\text { Clinical } \\
\text { form }\end{array}$} & \multirow{2}{*}{$\begin{array}{l}\text { Age at } \\
\text { lumbar } \\
\text { puncture }\end{array}$} \\
\hline & & $\begin{array}{l}\text { Total } \\
\text { method }\end{array}$ & $\overline{\text { Albumin }}$ & & & & \\
\hline 5 & $\begin{array}{l}0 \cdot 75 \\
T C A\end{array}$ & NK & NK & $\begin{array}{l}\text { IgG } 12 \cdot 1 \% \\
\text { Acrylamide }\end{array}$ & NK & ALS & 45 \\
\hline 7 & $\begin{array}{l}1 \cdot 52 \\
S S A\end{array}$ & 64 Biur & $\begin{array}{c}3 \cdot 9 \\
e^{+}\end{array}$ & $\begin{array}{l}\text { IgG } 4.6 \% \\
\text { Immunodiffusion }\end{array}$ & $\begin{array}{l}\text { Normal } \\
\text { Cellulose acetate }\end{array}$ & ALS & 47 \\
\hline 16 & $\begin{array}{l}0.50 \\
T C .4\end{array}$ & 65 Biur & $\begin{array}{l}\text { Normal } \\
\mathrm{et}^{+}\end{array}$ & NK & $\begin{array}{l}\text { Normal } \\
\text { Paper }\end{array}$ & Mixed & 53 \\
\hline 35 & $\begin{array}{l}0 \cdot 20 \\
T C A\end{array}$ & 64 Biur & $\mathrm{et}^{+}$ & NK & $\begin{array}{l}\text { Normal } \\
\text { Paper }\end{array}$ & PMA & 64 \\
\hline 36 & $\begin{array}{l}0.65 \\
T C A\end{array}$ & $\begin{array}{r}\text { Normal } \\
N K\end{array}$ & NK & NK & $\begin{array}{l}\text { Normal } \\
\text { Cellulose acetate }\end{array}$ & B & 60 \\
\hline 37 & $\begin{array}{l}0.53 \\
T C S\end{array}$ & NK & NK & $\begin{array}{l}\text { IgG } 16.3 \% \\
\text { Acrylamide }\end{array}$ & NK & ALS & 73 \\
\hline
\end{tabular}

TCA = Trichloroacetic acid; SSA = Sulphosalicylic acid; NK= Not known; ALS= Amyotrophic lateral sclerosis;

PMA $=$ Progressive muscular atrophy; $\mathbf{B}=$ Progressive bulbar palsy + See ref. 9.

Table 6 Histological change in MND with CSF protein $\geqslant 0.75 \mathrm{~g} / \mathrm{l}$

\begin{tabular}{|c|c|c|c|c|c|c|c|}
\hline \multirow[t]{2}{*}{ Case } & \multicolumn{3}{|l|}{ Brain } & \multicolumn{3}{|c|}{ Spinal cord } & \multirow{2}{*}{$\begin{array}{l}\text { Muscle } \\
\begin{array}{l}\text { Denervation } \\
\text { change }\end{array}\end{array}$} \\
\hline & $\begin{array}{l}\text { Motor } \\
\text { cortex }\end{array}$ & $\begin{array}{l}\text { Cranial nerve } \\
\text { nuclei }\end{array}$ & $\begin{array}{l}\text { Medullary } \\
\text { pyramids }\end{array}$ & $\begin{array}{l}\text { Ant horn } \\
\text { cells }\end{array}$ & $\begin{array}{l}\text { Glial } \\
\text { proliferation }\end{array}$ & $\begin{array}{l}\text { Anterolateral } \\
\text { column myelin }\end{array}$ & \\
\hline 1 & $\mathrm{NE}$ & NE & NE & + & - & + & NE \\
\hline 2 & - & - & + & + & + & + & NE \\
\hline 3 & - & - & + & + & + & + & + \\
\hline 4 & - & - & - & + & + & + & + \\
\hline 5 & - & + & - & + & + & + & NE \\
\hline 6 & $\mathrm{NE}$ & NE & NE & + & + & + & NE \\
\hline 7 & - & + & + & + & + & + & + \\
\hline
\end{tabular}

$\mathrm{NE}=$ not examined

$t=$ histological change seen

$-=$ no histological change seen

all. Gliosis of variable degree was also seen in the anterior horns. Myelin loss occurred in the anterolateral columns in all, varying from mild to moderately severe, occasionally with accentuation in the region of the lateral pyramidal tracts. The posterior columns were normally myelinated in all, thoracic nuclei were intact where reponted, and no inclusions were noted in the anterior horn cells. Three patients showed no obvious abnormality in the cranial nerves but two had some neurone loss and change in the hypoglossal nuclei. The medullary pyrmaids showed myelin degeneration in three cases. No obvious cell loss or change was seen in the available cerebral cortical sections. In three, skeletal muscle was examined and showed changes consistent with denervation. Only one patient had a section of peripheral nerve (the anterior tibial nerve) and this was normal.

The associated pathological findings in the 38 autopsied cases were not helpful. In 14 bronchopneumonia was noted. Cervical spondy- 
losis was found in three patients with elevated CSF protein. In case 3 the intervertebral discs between C5-6 and C6-7 were abnormally fragile and slightly yellowish but were not herniated. Case 4 had a small herniation of the disc between $\mathrm{T} 1$ and $\mathrm{T} 2$ which did not enter the spinal cord. Case 7 had radiological evidence of mild spondylotic changes in the mid and lower cervical region but measurements of the anteroposterior diameter of the spinal canal were normal. No pathological evidence of spondylotic myelopathy was found in any of these three cases. Three patients with CSF protein $<0.75 \mathrm{~g} / 1$ had evidence of cervical spondylosis too. Case 17 had normal X-rays of the cervical spine but there was marked protrusion of the lower five cervical and two mid thoracic intervertebral discs. Case 18 had marked backward protrusion of the intervertebral discs between C6-7 and C7-Tl, on hyperextension of the neck. Case 23 had some minor protrusion of C5-6.

Two patients with normal CSF protein had an incidental small meningioma of the falx.

\section{Discussion}

Elevation of CSF protein in MND is not rare. $15(39 \%)$ of the total of 38 patients had more than $0.50 \mathrm{~g} / 1$ and $8(22 \%)$ had $0.75 \mathrm{~g} / 1$ or more. Merritt and Fremont-Smith ${ }^{1}$ found raised CSF protein in 12 of their 33 cases. It was greater than $0.75 \mathrm{~g} / 1$ in three $(9 \%)$. Cumings ${ }^{2}$ and Castaigne et $a l^{10}$ respectively reported elevated CSF protein in $34 \%$ and $39 \%$ of their cases and Garde and Kjellin ${ }^{11}$ over $0.75 \mathrm{~g} / 1$ in $15 \%$.

Some consider that a CSF protein of more than $1 \mathrm{~g} / 1$ is so exceptional in MND that the diagnosis must be doubted. ${ }^{12}$ Cumings $^{2}$ found three cases with a CSF protein of $1 \mathrm{~g} / 1$ in 41 patients $(7 \cdot 3 \%)$ and we found three patients with total CSF protein $\geqslant 1 \mathrm{~g} / 1$ in 38 cases $(7 \cdot 8 \%)$. Brain et $a l^{13}$ mentioned one example of $1.40 \mathrm{~g} / 1$ in a patient with associated adenocarcinoma of the lung.

We found no obvious explanation for this elevation in CSF protein. Patients who had had myelography prior to CSF examination were excluded from study. There was no pleocytosis in the CSF and no pathological evidence of inflammation of the meninges. Three patients with elevated CSF protein had mild cervical spondylosis, but this was more marked in the three with normal protein. None had evidence of spondylotic myelopathy. High CSF protein is exceptional in cervical spondylosis unless there is evidence of spinal block. ${ }^{14}$ None of our patients had evidence of spinal block. Prolonged recumbancy is said to be associated with an elevation in CSF protein. ${ }^{15}$ Only one of the eight cases with CSF protein $\geqslant 0.75 \mathrm{~g} / 1$ was bedridden at the time of CSF examination (case 7). Two had normal gait (cases 3 and 5). The remaining five were all able to walk and were not chair or bed-ridden at the time of lumbar puncture. The highest red cell count in CSF (2300 per $\mu 1$, case 4 , table 5) would indicate that up to $0.003 \mathrm{~g} / 1$ of the total CSF protein could be accounted for by passage of blood into the CSF during lumbar puncture, but this amount is negligible.

The clinical features of all 38 patients analysed in this series do not differ substantially from others previously reported. (For recent reviews see references 16,17$)$. Six of our patients $(15 \%)$ survived five years or more, which is close to the $20 \%$ reported by Mulder and Howard. ${ }^{18}$ The small number of patients with progressive bulbar palsy (three) may be due to the criteria adopted for its diagnosis. If bulbar signs associated with lower motor neurone signs in the limbs are also included, then $15(38 \%)$ had bulbar palsy on admission to hospital, which is close to the $33 \%$ usually quoted. ${ }^{17}$

Lumbar puncture is accepted as a helpful diagnostic procedure in patients with suspected MND $^{17}$ but the significance, if any, of an elevation in CSF protein has not been studied. With this aim, we separated our 38 patients into two groups, those with CSF protein $\geqslant 0.75 \mathrm{~g} / 1$ and those below $0.75 \mathrm{~g} / 1$. Minor elevations in CSF protein are often disregarded by clinicians and the figure of $0.75 \mathrm{~g} / 1$ had the advantage that the Pandy test is known to become positive at this level and could offer an independent confirmation of the elevated CSF protein. ${ }^{19}$ Six of the eight patients with CSF protein $\geqslant 0.75 \mathrm{~g} / 1$ had the Pandy test performed and it was positive in all of them (table 4).

A striking finding is the negative correlation between age and CSF protein in MND patients (table 1) as compared with the positive correlation found in normals by Tibbling et al. ${ }^{8}$ The significance of this difference is obscure. In contrast, Müller-Jensen and Bernhardt ${ }^{20}$ found that mean CSF protein increased with age both in normals and in their 60 patients with a clinical diagnosis of MND.

Several series of young subjects with normal CSF protein have been reported and the disease was said to have a more prolonged course in most of them. ${ }^{3-5} 2122$ Our patients with CSF protein $\geqslant 0.75 \mathrm{~g} / 1$ were younger but their duration of illness was similar to those with lower CSF protein. The lack of a significant difference in time 
to severe incapacity (table 2) is against the clinical impression of a more rapidly incapacitating illness in them. However, their number was small and a definite conclusion on this point cannot be drawn.

Minor abnormalities in the composition of CSF protein in MND have been reported using paper electrophoresis, ${ }^{23}$ agar electrophoresis ${ }^{24-26}$ and discontinuous acrylamide rod gells. ${ }^{27}$ Castaigne et al $^{10}$ used cellulose acetate electrophoresis of CSF in 34 patients and 33 controls. MND patients had significantly higher mean values of alpha, beta and gamma globulins. Thirty per cent of their patients had elevation in CSF gamma globulin but serum protein electrophoresis was not reported. Garde and Kjellin ${ }^{11}$ found that ten of their 20 patients had a pathological pattern of CSF protein on quantitative paper electrophoresis, mostly of a barrier damage type, but some of a "degenerative" type, and a few had both CSF and serum abnormalities suggesting the possibility of a systemic disorder. Using isoelectric focusing in polyacrylamide gel, Kjellin and Stibler ${ }^{28}$ found a "finger print" pattern of CSF gamma globulins in all their nine patients with MND, consistent with barrier damage or transudation of serum proteins into the CSF. By monitoring the high molecular weight marker $\alpha_{2}$ macroglobulin, Schliep and Felgenhauer ${ }^{29}$ evaluated the bloodCSF barrier. Four patients with MND (total number not stated) had evidence of transudation of serum proteins but not of local synthesis of IgG within the nervous system.

If transudation of serum proteins is postulated as one mechanism of increase in CSF protein in MND, it would be expected that the level of IgG as a percentage of total CSF protein would progressively rise until it approached the level in serum $(16-20 \%) .{ }^{29}$ The increased IgG in CSF in our cases 37 and 5 (table 5) cannot therefore be presumed to be derived from local synthesis within the CNS. Unfortunately serum protein electrophoresis was not available in these patients but the highest CSF IgG is present in the patient with the lowest total CSF protein of the three so studied (case 37, table 5) and the lowest IgG in the patient with the highest CSF protein (case 7). The degree of barrier damage pattern as shown by isoelectric focusing did not necessarily correlate with the increase in CSF protein in the cases reported by Kjellin and Stibler ${ }^{28}$ (compare GB with BH in their table 3). Selective transudation of certain proteins in some cases or another mechanism of increase in CSF protein or a combination of both would be consistent with these findings. The presence of a protein abnormality in the highly alkaline fraction on isoelectric focusing in four of the nine patients of Kjellin and Stibler is interesting, as they think that this fraction may contain proteins which are associated with degeneration of nervous tissue.

The pathological changes in all patients, including the familial cases, were similar to those extensively described in several large series of the classical or sporadic form of MND. ${ }^{30-32}$ None of the seven cases with CSF protein $\geqslant 0.75 \mathrm{~g} / 1$ reviewed showed evidence of a possible structural alteration, at the light microscopic level, of vessels or leptomeningeal components. In case 4 there were a few lymphocytes scattered in the leptomeninges of the spinal cord. Lawyer and Netsky ${ }^{30}$ reported that perivascular lymphocytic infiltration was not uncommon, especially in the grey matter of the spinal cord, but this was not a feature in our cases.

We are grateful to Professor RW Gilliatt for helpful criticism. We also thank the physicians of the National Hospital, Queen Square, for permission to study the clinical records of their patients.

\section{References}

1 Merritt HH, Fremont-Smith F. The cerebrospinal fluid. Philadelphia: WB Saunders Company, 1937; 175.

2 Cumings JN. Motor neurone disease: biochemical aspects. Proc Roy Soc Med 1962; 55:1023-4.

3 Wall DW, Gelfand M. Motor neuron disease in Rhodesian Africans. Brain 1972; 95:517-20.

4 Osuntokun BO, Adeuja AOG, Bademosi O. The prognosis of motor neuron disease in Nigerian Africans. A prospective study of 92 patients. Brain 1974; 97:385-94.

5 Peiris JB, Seneviratne KV, Wickremasinghe HR, Boralessa H, Chandrasekara MA. Motor neuron disease in the young in Sri Lanka. Inst Neurol Madras Proc 1976; 6:160-8.

6 Meulemans O. Determination of total protein in spinal fluid with sulphosalicylic acid and trichloroacetic acid. Clin Chim Acta 1960; 5: 757-761.

7 Pennock CA, Passant LP, Bolton FG. Estimation of cerebrospinal fluid protein. J Clin Path 1968; 21:518-20.

8 Tibbling G, Link H, Ohman S. Principles of albumin and IgG analysis in neurological disorders. I. Establishment of reference values. Scand J Clin Lab Invest 1977; 37:385-90.

9 Goa J. A micro biuret method for protein determination; determination of total protein in cerebrospinal fluid. Scand J Clin Lab Invest 1953; 5:218-22.

10 Castaigne P, Lhermitte F, Schuller E, Rouques 
C. Les protéines du liquide céphalo-rachidien au cours de la sclérose latéral amyotrophique. $R e v$ Neurol (Paris) 1971; 125:393-400.

11 Garde A, Kjellin KC. Diagnostic significance of cerebrospinal-fluid examinations in myelopathy. Acta Neurol Scand 1971; 47:555-68.

12 Rowland LP, Layser RB. Chapter 37 In: Baker AB, Baker LH, eds. Clinical Neurology. New York: Hayer and Row, 1971; Vol. III, 12.

13 Brain Lord, Croft PB, Wilkinson M. Motor neurone disease as a manifestation of neoplasm (with a note on the course of classical motor neurone disease). Brain 1965; 88:479-500.

14 Wilkinson M. Motor neuron disease and cervical spondylosis. In: Norris FH, Kurland LT, eds. Motor Neuron Diseases. New York: Grune and Stratton. 1969; 130-4.

15 Cumings JN. The diagnostic value of the examination of the cerebrospinal fluid. Postgrad Med J 1952; 28:587-91.

16 Bonduelle M. Amyotrophic lateral sclerosis. In: Vinken PJ, Bruyn GW, eds. Clinical Neurology. Amsterdam: North Holland Publishing Co. 1975; Vol. 22, 281-338.

17 Rose FC. Clinical aspects of motor neuron disease. In: Rose FC, ed. Motor neurone disease. London: Pitman Medical Publishing Co. 1977: 13.

18 Mulder DW, Howard FM. Patient resistance and prognosis in amyotrophic lateral sclerosis. Mayo Clinic Proc 1976; 51:537-41.

19 Thompson EJ, Norman PM, MacDermot J. The analysis of cerebrospinal fluid. Brit J Hosp Med $1975 ; 14: 645-52$.

20 Müller-Jensen A, Bernhardt W. Unsere Erfahrungen bei der myatrophischen Lateralsklerose. Nervenarzt 1973; 44:143-9.

21 Meenakashisundaram E, Jagannathan K, Ramamurthi B. Clinical pattern of motor neuron disease seen in younger age groups in Madras. Neurology (India) 1970; 18: Suppl. 1:109-12.

22 Aimard G, Bady B, Boisson D, Trouillas P, Devic M. Sclerose Latérale Amyotrophique Sur- venue avant 40 ans. Remarques à propos de 25 observations. Rev Neurol (Paris) 1976; 132: 563-6.

23 Sarteschi P, Fabiani P. Limiti All' Indagine Elettroforetica su carta della crasi Proteica Ematoliquorale in Malati Neurologici e Psichichi. Rass Studi Psich 1956; 45:1193-228.

24 Laterre EC, Heremans JF, Demanet G. La pathologie des proteines du liquid céphalorachidien. Etude electrophorétique et immunoélectrophoretique. (600 observations). Rev Neurol (Paris) 1962; 107:500-21.

25 Bokonjic R, Renders J. Etude électrophorétique de 400 liquides cephalo-rachidiens pathologiques. Acta Neurol Psychiat Belgica 1964; 64:769-76.

26 Lowenthal A. Agar gel electrophoresis in neurology. New York: Elsevier Publishing Co. 1964: 98-100, 118-9.

27 Roboz Einstein E, Macrae D. Spinal fluid analysis in amyotrophic lateral sclerosis. In: Norris FH, Kurland LT, eds. Motor Neuron Diseases. New York: Grune and Stratton. 1969: 175-178.

$28 \mathrm{~K}$ jellin $\mathrm{KG}$, Stibler $\mathrm{H}$. Isoelectric focusing and electrophoresis of cerebrospinal fluid proteins in muscular dystrophies and spinal muscular atrophies. J Neurol Sci 1976; 27:45-57.

29 Schliep G, Felgenhauer K. Serum-CSF protein gradients, the blood-CSF barrier and the local immune response. J Neurol 1978; 218:77-96.

30 Lawyer T, Netsky MG. Amyotrophic lateral sclerosis. A clinico-anatomic study of fifty-three cases. Arch Neurol Psychiat (Chicago) 1953; 69: 171-92.

31 Brownell B, Oppenheimer DR, Hughes JT. The central nervous system in motor neurone disease. J Neurol Neurosurg Psychiat 1970; 33: 338-57.

32 Castaigne P, Lhermitte F, Cambier J, Escourolle $R$, Le Bigot $P$. Etude neuropathologique de 61 observations de sclerose latéral amyotrophique. Rev Neurol (Paris) 1972; 127:401-14. 